\title{
特集：有機分子の定性・構造解析 REVIEW
}

\section{$N$ 結合型糖鎖の負イオン化とフラグメンテーション}

\author{
Ionization and Fragmentation of \\ $N$-Linked Glycans in Negative-Ion Mode
}

西風隆司

Takashi NisHikAzE

株式会社島津製作所 田中耕一記念質量分析研究所 Koichi Tanaka Mass Spectrometry Research Laboratory,

Shimadzu Corporation

(Received August 22, 2017; Accepted September 22, 2017)

\section{1.はじめに}

第三の生命鎖と呼ばれる糖鎖は生体内にさまざまな形で 存在する。なかでも，タンパク質への翻訳後修飾としての 糖鎖付加はタンパク質そのものの性質や働きを左右する重 要な因子である。

糖鎖修飾の解析には得たい情報に応じてさまざまなアプ ローチ（単糖解析, 遊離糖鎖解析, 糖ペプチド解析, 糖夕 ンパク質解析など）が存在する ${ }^{1)}$. なかでも, 最も詳細に 糖鎖の構造情報が得られるのは, タンパク質から切り離し た遊離糖鎖として解析する手法である。近年, 質量分析 （Mass spectrometry; MS）は糖鎖解析において中心的な役 割を果たしていると言ってょい。しかし，MSを用いた糖 鎖の構造解析は，質量では区別できない異性体が多いこと や，糖鎖の多くが分岐構造を持つことなどから本質的に難 しい分野である.

本概論では, ユニークな構造情報が得られる負イオン モード衝突誘起解離 (collision-induced dissociation; CID) に よる糖鎖構造解析技術を紹介する. 実際の分析手順とは逆 となるが,ここではまず糖鎖, 特にN $N$ 結合型糖鎖の負イオ ンフラグメンテーションの特徴を述べ, 次に糖鎖の負イオ ン種を与えるためのイオン化について述べる.これらの分 析の可否を支配する因子を熱化学的な観点から考察したい.

\section{2. 糖鎖の構造解析の難しさ}

糖鎖は単糖残基がグリコシル結合でつながったもので, グリコシル結合は酸や塩基で容易に加水分解される．糖鎖 をイオン化し, 質量分析計の中で気相イオンに対して CID を行った場合でも，各残基間のグリコシル結合開裂を中心 とした分解過程を経る。しかし, 糖鎖は分岐構造を持つも のが多く, 加えて単糖残基間の結合にも(1)位置異性体と

連絡先：nishikaz@shimadzu.co.jp
(2)アノメリック位の立体配置による $\alpha$ と $\beta$ の異性体が存在 するため, グリコシル結合のみの開裂では構造の推定に不 十分である.

グリコシル結合中心の開裂は正イオンモードで誘起され やすい．もちろん，正イオンモードCIDで糖鎖構造が推 定できないわけではなく, 構成単糖の情報が得られやすい 正イオンモードは現在の糖鎖構造解析の主流と言ってよ い，また，質量も構成単糖も同じ異性体であっても CID のスペクトルパターンが異なる場合があり，事前に当該装 置で構造既知標品についての多段階CID スペクトルパ ターンを把握していれば標品との $\mathrm{MS}^{n}$ スペクトルパター ンマッチングで糖鎖の構造異性体を判別していくことも可 能である2),3).

しかし, データベースにない新しい構造の糖鎖や, デー タベースを保有していない場合など，いわゆる de novoで 構造解析を行いたい場面はある。また，異性体に関する情 報を得たい，分岐構造を解析したいなど，異なる視点から の構造情報を得たい場面もある。そのようなときの選択肢 の一つとして負イオンモードの活用が挙げられる.

先に挙げた異性体の解析がすべて負イオンCIDで行え るわけではないが, 分岐構造の解析やフコースの位置特定 などには負イオンCIDが有用である.

\section{3. 糖鎖の負イオン構造解析の特徵}

負イオンモードでの糖鎖のフラグメンテーションは, メ カニズムも得られるイオン種も全く異なる。正イオンの場 合はナトリウムイオンやプロトンなどの正電荷が乗りやす い部分のイオンがプロダクトイオンとして観測される傾向 にあるが，これから論じるような糖鎖負イオンの場合は， CID条件下での電子移動によって糖鎖の還元末端側が ニュートラルロスしやすく, 非還元末端側のプロダクトイ オンを生じやい。また，結合位置解析に有用な環開裂によ り生じるプロダクトイオンが多いのも特徴である. 
(a)

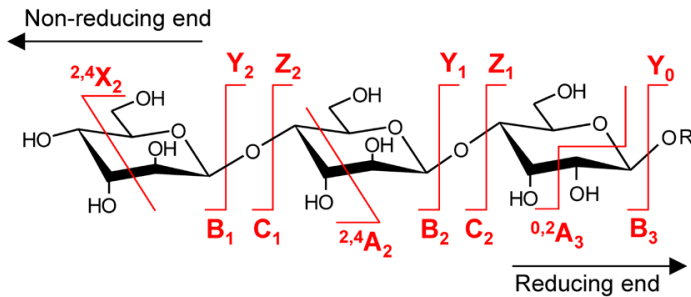

(b)

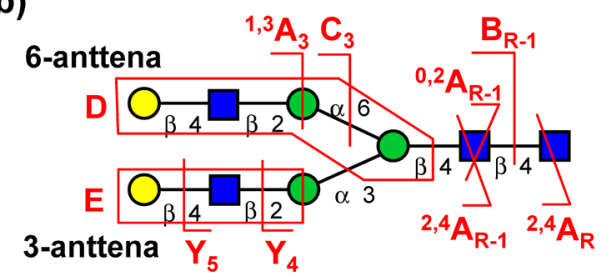

(c)

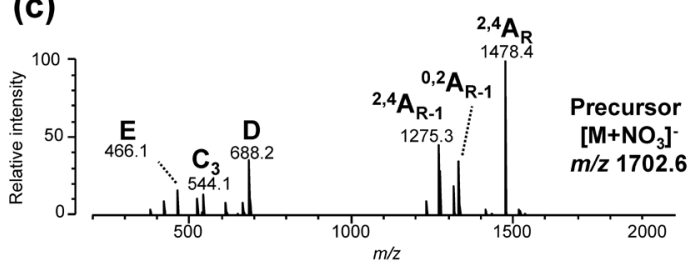

(d)

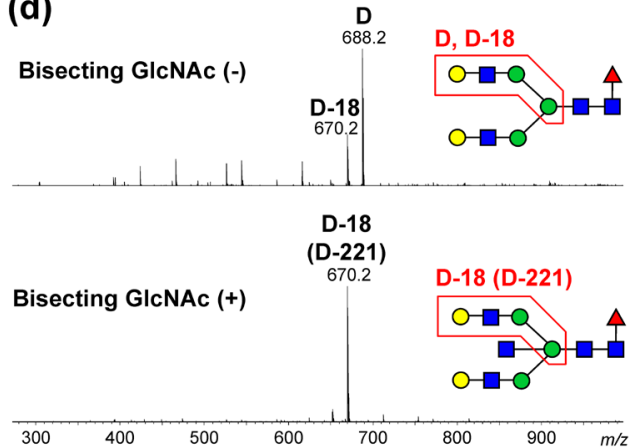

(e)

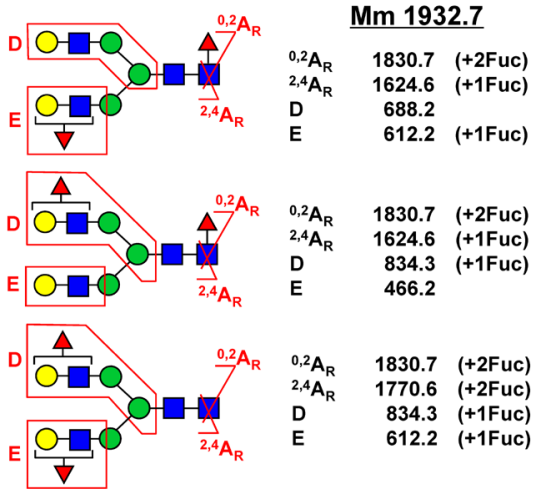

図1. 典型的な $N$ 結合型糖鎖の負イオンCID スペクトルとその解釈． (a) Domon \& Costelloのフラグメント命名法, (b, c) NA2 型糖鎖 の $\mathrm{NO}_{3}^{-}$付加体から取得した負イオンCID スペクトルとその解釈，(d) bisecting GlcNAcの有無によるDイオンの検出のされ方 の違い, (e) フコースの位置に応じた各種プロダクトイオン $m / z$ のシフト．負イオン $\mathrm{CID}$ スペクトルは $\mathrm{NO}_{3}^{-}$付加体をプリカー サーとして得たものであるが, 脱プロトン体から生じているプロダクトイオンと一致する.

ここからは $N$ 結合型糖鎖の負イオンフラグメンテーショ ンに焦点を当てる．N結合型糖鎖の負イオンCIDの研究は Harveyらによって精力的に進められ，その特徴も明らか となっている(4) 10).

負イオン構造解析でのプリカーサーである脱プロトン分 子は後述のように不安定で, そのCIDは単純な一次開裂 を中心とする機構によってプロダクトイオンが生じやす く, 元の構造を直接的に反映したスペクトルになりやす い.それゆえに“診断的 (diagnostic)” な解析が行え, あ いまいさの少ない構造解析が可能となる。 また, 正イオン モードCIDで問題になる単糖の転移反応も負イオンモー ドでは起こりにくい11).

図 1 に典型的な $N$ 結合型糖鎖の負イオン CID スペクトル とその解釈を示した. プロダクトイオンの命名はDomon \& Costelloのものに準ずる ${ }^{12)}$ (図 1a).N結合型糖鎖の負 イオンCIDでは, 主として非還元末端を含むプロダクト イオンが生じる. 環開裂に由来する Aイオンやグリコシル 結合の開裂に由来するCイオンが生成しやすいが, 最も特 徵的なのは $N$ 結合型糖鎖を構成する二つのアンテナ構造を 反映するDイオンやEイオンの生成である（図 $1 \mathrm{~b}$ 赤枠参 照). Dイオンはトリマンノシル構造の中央のマンノース から 6-アンテナ側の残基をすべて含むイオンであり, 負イ オンCIDのマススペクトル解析ではこのDイオンを見つ けることがスペクトル解釈の第一歩といってもよい。これ に加えて，3-アンテナ側のEイオンも検出できればょり正 確であるが, 実際はプリカーサー質量とDイオンの質量
から $\mathrm{E}$ イオンの質量が計算可能である. 各アンテナ構造が 同じでも Dイオンと $\mathrm{E}$ イオンの構造は異なるので, 区別に 迷うことはない.

トリマンノシル構造の中央のマンノースに対して付加的 にN-アセチルグルコサミン（GlcNAc）が結合するbisecting GlcNAcの有無は, Dイオンの出方によって判別できる. 通常は，Dイオンに加えてそこからの脱水イオンである D-18イオンが両方検出されるが，Dイオンが検出されずに D-18イオンのみが検出されれば, bisecting GlcNAcが付加 していると判断できる（図1d）。本来は，Dイオンにbisecting GlcNAcも含まれるべきなのだが，Dイオンからは bisecting GlcNAcが $\mathrm{H}_{2} \mathrm{O}$ を伴って速やかに脱離するので D-18のみが生じる．文献によっては，このD-18をD-221 （221=GlcNAc 203+ $\mathrm{H}_{2} \mathrm{O}$ 18）と表記しているものもある.

フコース位置の特定は負イオン CID の得意とするとこ ろで, Dイオンに含まれれば6-アンテナ側, Eイオンに含 まれれば3-アンテナ側と判別でき, コアフコースの場合は プリカーサーまたは ${ }^{0,2} \mathrm{~A}_{\mathrm{R}}$ に対する ${ }^{2,4} \mathrm{~A}_{\mathrm{R}}$ イオンとの質量差 により判別できる（図 1e).

\section{4. 質の高い負イオン CID スペクトル取得のために}

このような診断的構造解析を可能にする質の高い負イオ ンCID スペクトルを取得するには, 試料側にいくつか条 件がある。

(1) $N$ 結合型糖鎖にシアル酸がない, またはシアル酸のカル ボキシル基が修飾により中性化されていること。 
(2)還元末端がラベル化されていてもよいが，還元により開 環していないこと.

以下に詳細を述べる。

(1)シアル酸を含む糖鎖は比較的安定な脱プロトン分子を生 じるが, CIDではシアル酸の脱離を含むさまざまなフラ グメントが混在することになり, 診断的解析には向かな い. そのため, シアル酸のカルボキシル基を修飾によっ て中性化した状態で負イオンCIDを行うのが好ましい. エステル化を採用した報告もあるが, エステル構造は負 イオン CID 条件下でアルコールの脱離を生じるため煩 雑なスペクトルになる ${ }^{8)}$. この点, アミド化で安定化し たシアル酸からはアミン類の脱離は生じないためより適 する ${ }^{13), 14)}$.

(2)還元的アミノ化（図2）による糖鎖還元末端のラベル化 は, 高速液体クロマトグラフィー（high performance liquid chromatography; HPLC）での蛍光 / UV 検出や MSでの感度向上のために古くから行われている. 本法 では, MS 糖鎖還元末端にアミンを反応させ可逆的に シッフ塩基を生じさせるが, さらに還元を行うことで不 可逆的なラベル化体を生じさせる. シッフ塩基は開環構

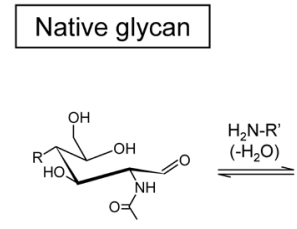

Glycan (open-ring)

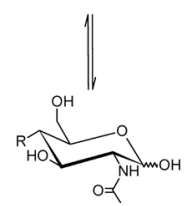

Glycan (hemiacetal)

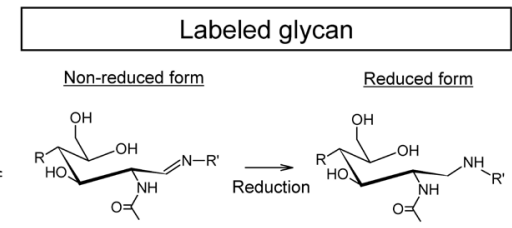

Schiff base

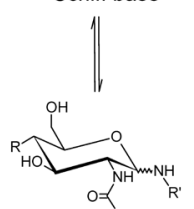

(Glycosylamine form)
図2. 還元的アミノ化による糖鎖ラベル化反応の概要. 反応 に直接関与する還元末端GlcNAcのみ示している.
造だがグリコシルアミン構造と平衡状態にあり，われわ れのLC-NMRによる実験結果ではほぼすべてがグリコ シルアミン構造，つまり閉環構造であることがわかっ た.この状態での負イオンCIDの特徵は非ラベルのも のと何ら変わらないが, 還元により根元のGlcNAcが完 全に開環すると，環内での電子移動が妨げられ， ${ }^{2,4} \mathrm{~A}_{\mathrm{R}}$ といった環開裂イオンが生じにくくなる，さらに，脱プ ロトン分子の安定性が増大するためCIDを行うにはよ り強いエネルギーが必要となる。結果として, 二次開裂 を起こしやすくなるため，そのCID スペクトルは複数 箇所開裂を含む複雑なものになり, 診断的解析には適さ ない. したがって，還元末端のラベル化は行ってもよい が，還元は行わないほうがよい10),15).

先に述べたような糖鎖の構造を直接的に反映する診断的 なプロダクトイオンの生成には『糖鎖の脱プロトン分子が 不安定であること』が大きく貢献している．上に述べた条 件を満たすタイプの糖鎖分子からのプロトン引き抜きは主 にコア構造の二つの GlcNAcの3 位の水酸基から起こると 考えられており，そこからの電子移動によって環開裂や特 殊な C, D, Eイオンなどが生じるモデルが提案されてい る ${ }^{5)}$.プロトン引き抜きで生じた反応性に富む負イオンは ほぼ自壊するような形でプロダクトイオンを生じる。シア 儿酸があるとそこに負電荷が固定されてしまい, 負イオン が安定化する。また，理論的な裏づけは乏しいが，実験的 に還元末端GlcNAcの還元が脱プロトン分子を安定化する ことが示されている15).

すなわち，N結合型糖鎖の負イオン構造解析には, 脱プ ロトン分子からCIDを取得したいが脱プロトン分子を安 定化してはいけない，というジレンマが存在する.プリ カーサーが不安定というのは分析技術上不利となり, $\mathrm{MS}^{1}$ スペクトル中にインソース分解（in-source decay; ISD）に よるフラグメントイオンが混じる場合もあり, そもそもイ オン化しない場合もある.

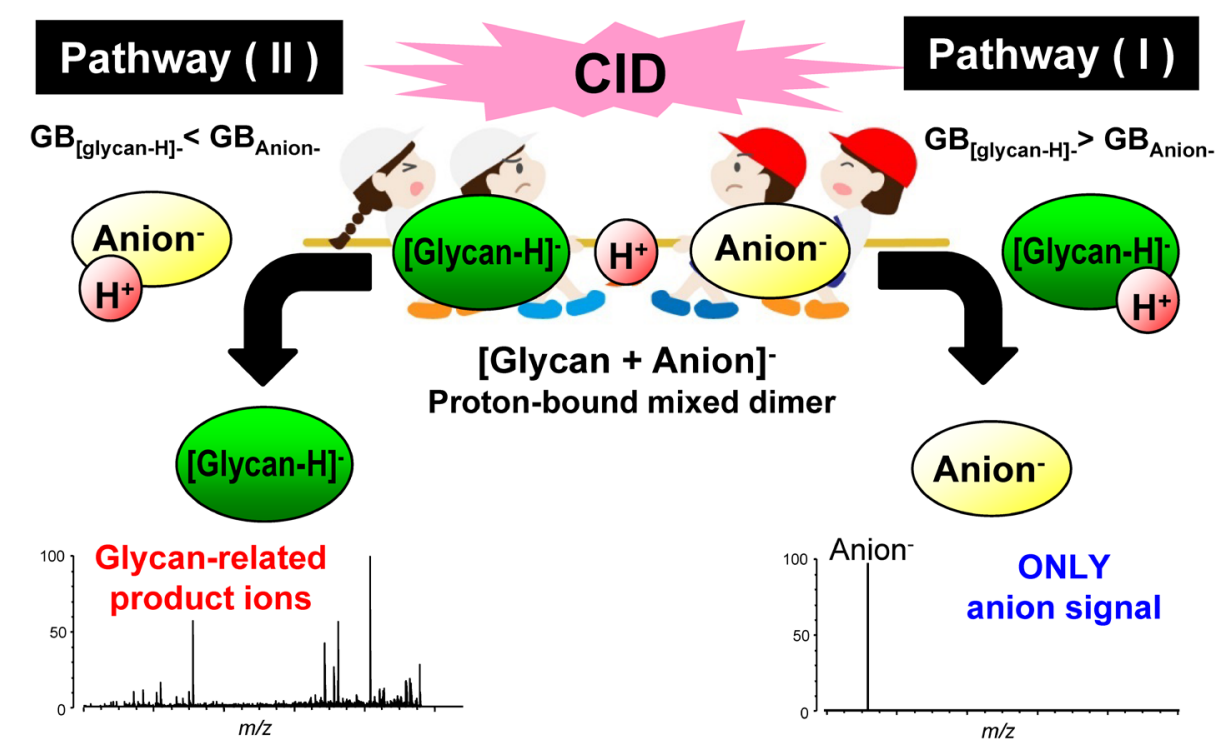

図3. 糖鎖のアニオン付加体をCID したときのフラグメンテーション経路の概略模式図. 


\section{5. アニオン付加体からのCID}

このジレンマを解消するのが，アニオンを付加させた状 態で安定に負イオン化し，CIDはそのアニオン付加体をプ リカーサーとして取得する，という手法である。

一口にアニオンといっても種類は多い.アンモニウム塩 などの試薬として容易に入手可能なものでも, $\mathrm{F}^{-}, \mathrm{Cl}^{-}$, $\mathrm{Br}^{-}, \mathrm{I}^{-}, \mathrm{HSO}_{4}^{-}, \mathrm{H}_{2} \mathrm{PO}_{4}^{-}, \mathrm{NO}_{3}^{-}, \mathrm{SCN}^{-}$, etc. などがある.もち ろん, アニオンであれば何でもよいわけではなく, 糖鎖の 構造解析に使えるアニオンは試料となる糖鎖とアニオンの 物理化学的性質によって決まる。

以下，糖鎖のアニオン付加体について議論する。

中性糖鎖にアニオンが付加した複合体は，互いにプロト ンを共有した proton-bound mixed dimer とみなせる ${ }^{16)}$.

\section{$[\text { Glycan- } \mathrm{H}]^{-} \cdots \mathrm{H}^{+} \cdots$ Anion ${ }^{-}$}

糖鎖にアニオンが付加した状態をプリカーサーとして CID 行った際のフラグメンテーション経路としては, 大 きく次の二つが考えられる.

糖鎖アニオンのプロトンを引き抜く能力がアニオンより 大きければ，アニオンが外れるのみで糖鎖のイオンは生じ ない（図3 経路I).

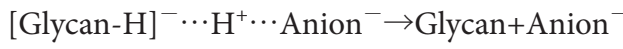
一方で, アニオンのプロトンを引き抜く能力が糖鎖アニオ ンより大きければ, 脱プロトン化糖鎖が生じる（図3 経 路II).

${\text { [Glycan-H }]^{-} \cdots \mathrm{H}^{+} \cdots \text { Anion }}^{-} \rightarrow[\text { Glycan-H }]^{-}+$HAnion 糖鎖の構造解析が可能なのは後者であり, CIDの結果生じ た糖鎖アニオン [Glycan-H] ${ }^{-}$がそのままフラグメンテー ションを起こし, 糖鎖のプロダクトイオンが得られること となる.

表1. 代表的なアニオンの気相塩基性度（GB）

\begin{tabular}{lc}
\hline Anion & $\begin{array}{c}\mathrm{GB} \\
(\mathrm{kJ} / \mathrm{mol})\end{array}$ \\
\hline $\mathrm{PF}_{6}^{-}$ & 1,157 \\
$\mathrm{BF}_{4}^{-}$ & 1,204 \\
$\mathrm{HSO}_{4}^{-}$ & 1,265 \\
$\mathrm{I}^{-}$ & 1,294 \\
$\mathrm{NO}_{3}^{-}$ & 1,330 \\
$\mathrm{Br}^{-}$ & 1,332 \\
$\mathrm{SCN}^{-}$ & 1,343 \\
$\mathrm{H}_{2} \mathrm{PO}_{4}^{-}$ & 1,351 \\
$\mathrm{Cl}^{-}$ & 1,373 \\
$\mathrm{~F}^{-}$ & 1,531 \\
\hline
\end{tabular}

*各数值の詳細は文献 23 を参照のこと.

表2. 糖鎖アニオンの気相塩基性度（GB）

\begin{tabular}{lc}
\hline Neutral glycan & $\begin{array}{c}\mathrm{GB}_{[\mathrm{M}-\mathrm{H}]^{-}} \\
(\mathrm{kJ} / \mathrm{mol})\end{array}$ \\
\hline D-Glucose & 1,398 \\
Sucrose & 1,373 \\
NA2 glycan & $1,294 \sim 1,330$ \\
\hline
\end{tabular}

*各数值の詳細は文献 17 および 23 を参照のこと.
プロトンを引き抜く能力とは，プロトンを得たときの自 由エネルギー変化の負值, すなわち気相塩基性度（Gasphase basicity；GB）に相当する. 表 1,2 に代表的なアニオン と糖鎖アニオンの GBを示したが，ここで議論する GBはす ベて（プロトンが脱離した）アニオンの状態での GBであ る。アニオンがプロトンを得て中性化する能力であり，中 性分子がプロトンを得てカチオン化する能力とは異なる.

グルコースやスクロースなど小さな糖鎖アニオンの GB は高く，プロトンを引き抜き糖鎖アニオンを生じさせるに

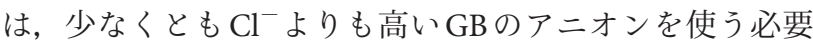
があった。一方で，より巨大な $N$ 結合型糖鎖の GBは低 く, $\mathrm{NO}_{3}^{-}$程度でも糖鎖のプロダクトイオンが得られる ${ }^{4)}$.

$N$ 結合型糖鎖に対して $\mathrm{Cl}^{-}$や $\mathrm{F}^{-}$など高い $\mathrm{GB}$ を有するア ニオンを付加させてもよいが，実用性は低い. $\mathrm{Cl}^{-}$の同位 体分布により $\mathrm{MS}^{1}$ スペクトルが複雑になるというのもあ るが，主な理由は高いGBを有するアニオンを用いると良 好なイオン生成量が得られないからである．以下，アニオ ンのGB とイオン生成量の関係について議論する.

\section{6. アニオン付加体の生成}

アニオン付加体は proton-bound mixed dimer modelによ るとアニオンと糖鎖アニオンがプロトンを共有している複 合体とみなせるため，GBの差が大きいと複合体を作りに くく安定な付加体とならない16). 図4 4 はある条件でアニオ ンのみを変化させた際の NA2 型中性糖鎖のアニオン付加 体生成量の比較を示している，CIDにおいて， I- 付加体か らは糖鎖のプロダクトイオンが取得できず, $\mathrm{NO}_{3}^{-}$付加体 からは取得できるので，NA2型糖鎖アニオンの GB は $1,294 \sim 1,330 \mathrm{~kJ} / \mathrm{mol}$ と推定される.このことは，NA2型中 性糖鎖が $\mathrm{I}^{-}$付加体や $\mathrm{HSO}_{4}^{-}$付加体で強いイオン生成量が得 られていることからも推定できる. $\mathrm{HSO}_{4}^{-}$付加体のイオン 生成量が高いのは水素結合などによって複合体がより安定 化しているためと考えられる.

したがって，実用的には分析対象の糖鎖と似たような GBのアニオンを用いるのが好ましいが，これまでに述べ たCID時の “プロトン綱引き”との関係で，構造解析を 行うには糖鎖アニオンより高いGBのアニオンを用いなけ ればならない。

\section{7. アニオン付加体の生成と MALDI マトリックス}

オミクス系計測分野では複雑な試料を HPLCなどで分離 しながらイオンサプレッションを低減しエレクトロスプ レーイオン化（electrospray ionization; ESI）でイオン化す る場合が多いが，糖鎖の分析ではマトリックス支援レー ザー脱離イオン化（matrix-assisted laser desorption/ionization; MALDI）もよく用いられる。これには，ペプチドなどと 比べて糖鎖は官能基のバリエーションがそしいため, 物理 化学的な性質に差が生じにくくお互いにイオンサプレッ ションを受けにくい，常に一価イオンが生じるのでスペクト ルの解釈が容易でスループットも高い, などの理由がある.

MALDIで糖鎖のアニオン付加体を生じさせるには，適 


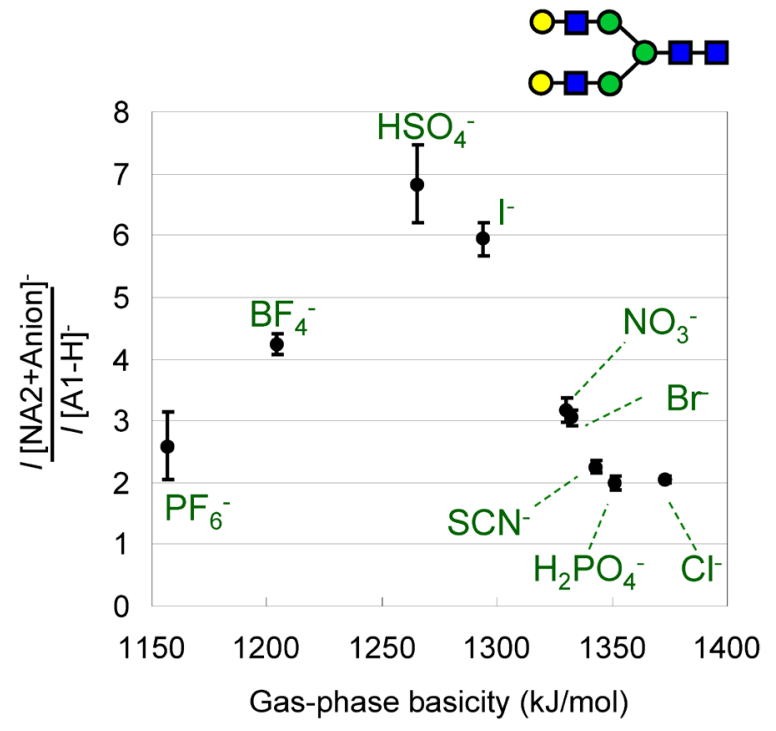

図4. NA2 型糖鎖（右上）の負イオン生成量評価, $\mathrm{G}_{3} \mathrm{CA}$ 液 体マトリックスを用い, 各アニオンのアンモニウム塩 を加えてアニオン付加体を生成させた. シアル酸を有 する $\mathrm{A} 1$ 型の $[\mathrm{A} 1-\mathrm{H}]^{-}$を内部標準としてノーマライズ し評価した。文献23より許可を得て使用, Copyright (2012) American Chemical Society.

切なマトリックスを用いることが肝要である. MALDIにお けるマトリックスは脱離イオン化の担い手であり, 試料の 量に対して大過剩用いるが, マトリックスがアニオンにプ ロトンを渡して中性化してしまうようでは, 糖鎖に対する 効率的な付加は望めない. つまり, 下記の反応が起こらな いよう，アニオンよりも高いGBを持つマトリックス（より 正確には脱プロトン化したマトリックスアニオンの状態で 高いGBを持つマトリックス）を選ばなければならない17).

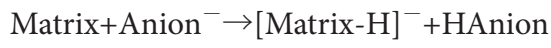

文献が存在する代表的なマトリックスアニオンのGBを 表3に示した。 $\beta$-Carboline alkaloidの一種である harmine や norharman は高いGBを有しており, 糖鎖の $\mathrm{Cl}^{-}$付加体 の生成に用いられた ${ }^{18)}$. スクロースなどの短い糖鎖は GB が高いので，それからプロトンを引き抜こうとするとより 高い $\mathrm{GB}$ の $\mathrm{Cl}^{-}$を付加させなければならず，イオン化時に $\mathrm{Cl}^{-}$を中性化させないためにはさらに GBの高いマトリッ クスを使う必要があった。

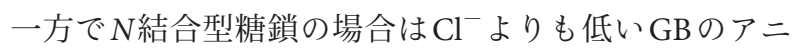
オンを用いても負イオンCID スペクトルが取得できるた め, マトリックス選択の幅は広がる.

表3に挙げた中で最も GB の高いマトリックスは3-AQ であるが，アミノ基を有するために糖鎖の還元末端と反応 してシッフ塩基を与える. Rohmerらは3-AQをマトリッ クスとして用いるとともに, 糖鎖の MALDI プレート上で のラベル化に用いたが, 硝酸アンモニウムを添加しておき $\mathrm{NO}_{3}^{-}$付加体としてイオン化し構造解析を行った ${ }^{19)}$. 著者 らも3-AQが主体となる液体マトリックスを用いたオン ターゲットラベル化法を開発したが, リン酸アンモニウム を添加しておき $\mathrm{H}_{2} \mathrm{PO}_{4}^{-}$付加体としてイオン化した ${ }^{20), 21)}$.

MALDIでの効率的な $N$ 結合型糖鎖のアニオン付加体生
表3. 代表的な MALDI マトリックスの気相塩基性度（GB）

\begin{tabular}{lcc}
\hline \multicolumn{1}{c}{ Matrix } & $\begin{array}{c}\mathrm{GB}_{[\mathrm{M}-\mathrm{H}]^{-}} \\
(\mathrm{kJ} / \mathrm{mol})\end{array}$ & $\begin{array}{c}\mathrm{GB}_{[2 \mathrm{M}-\mathrm{H}]^{-}} \\
(\mathrm{kJ} / \mathrm{mol})\end{array}$ \\
\hline 3-Aminoquinoline (3-AQ) & 1,451 & $\mathrm{n} / \mathrm{a}$ \\
Harmine & $1,373 \sim 1,407$ & $\mathrm{n} / \mathrm{a}$ \\
Sinapinic acid (SA) & 1,400 & 1,285 \\
Ferulic acid (FA) & 1,399 & 1,286 \\
2,5-Dihydroxybenzoic acid (DHBA) & 1,329 & $\mathrm{n} / \mathrm{a}$ \\
2,4,6-Trihydroxyacetophenone (THAP) & 1,324 & $\mathrm{n} / \mathrm{a}$ \\
\hline
\end{tabular}

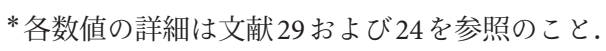

成に向け，Domannらは固体マトリックスとアニオン 種 ${ }^{22)}$, 筆者らは液体マトリックスとアニオン種との組み 合わせを検討した ${ }^{23)}$. 硝酸アンモニウムを添加したTHAP 固体マトリックスや, 硝酸アンモニウムやテトラフルオロ ホウ酸アンモニウムを添加した $\mathrm{G}_{3} \mathrm{CA}$ 液体マトリックスが 最適であった。

THAPが $\mathrm{NO}_{3}^{-}$付加体生成に適するのなら，それよりも GBの高いDHBAなどもアニオン付加体を生じてもよいと 思われるが, 実際は非効率的である。推測の域を出ない が, DHBAがアニオン付加に適さないのは, マトリックス の二量体以上のクラスターがアニオン中性化の担い手にな るからかもしれない. シナピン酸アニオンなどは二量体に なるとGBが下がる（つまり，アニオンを中性化しやす い）ことが知られている ${ }^{24)}$.

マトリックスによっては添加したアニオンを異物として 排除しながら結晶化する場合もあり, 添加したアニオンの 量がそのままイオン分子反応の舞台となるプルーム内での アニオン濃度に反映されるわけではない，液体マトリック スの場合は均一と期待されるが， 3-AQ/CHCA や3-AQ/CA などは溶媒が乾燥する過程で相分離が起こるのでアニオン 濃度が均一でなくとも不思議ではない25). アニオンの種 類によってはアニオンのクラスターイオンが顕著に検出さ れる場合もある。

結局のところ, 糖鎖の負イオン化のためのマトリックス とアニオンの組み合わせ, およびそのプレパレーションは 試行錯誤による経験的な側面も強い. 理論的な裏づけも乏 しく『マトリックスとの相性が…』と言わざるをえない場 面もある.これはマトリックスそのものの探索にも言える ことであるが, イオン化現象を完全に理解するところまで われわれの知見は至っていないので, 脱離イオン化の各種 素過程と得られるスペクトルを結びつけるような基礎研究 は今後も必要である.

\section{8. 糖鎖負イオンCID 解析の最近の発展}

前述のように，負イオンCID を用いた $N$ 結合型糖鎖構 造解析は, シアル酸の修飾と組み合わせることが好まし い. シアル酸の修飾には結合様式非特異的なものと特異的 なものがあり, 後者ではシアル酸の結合様式 $(\alpha 2,3-/ \alpha 2,6-)$ に応じて質量の異なる修飾を行うことで結合異性体を区別 することができる．特にアミド化を用いたものは負イオン CID を行った際に修飾部分の分解が起こらないため適す 
る. 最近, 著者らもアミド化ベースの結合様式特異的修飾 法SALSA $^{\mathrm{TM}}$ (sialic acid linkage-specific alkylamidation) を 開発した ${ }^{26)}$. SALSA ${ }^{\mathrm{TM}}$ と負イオンCIDを組み合わせるこ とで，より詳細な構造解析が可能となる.

情報量を増やすという観点では, 負イオンCID と ion mobilityを組み合わせるというアプローチも行われてい

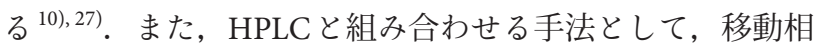
に $\mathrm{F}^{-}$を添加することで脱プロトン分子の生成を促す手法 も開発されている ${ }^{28)}$.

昨今のオミクス系計測分野では正イオンモードが通常用 いられるが，糖鎖解析に関しては本概論で紹介したような 負イオンの活用はいわば別軸の情報を与えるものなので, うまく併用することでょり正確に糖鎖構造を把握できるよ うにもなる。

\section{9. ま と め}

本概論では, $N$ 結合型糖鎖負イオン構造解析のためのア ニオン付加体の生成とフラグメンテーションについて，そ の現象を取り巻く物理化学的な性質の中から気相塩基性度 （GB）に焦点を当てて述べた。プロトン引き抜き能力に相 当する気相塩基性度は，一見負イオン解析には無関係な熱 化学的物理量のようにも感じられるが，実際はアニオン付 加体の生成やその先のフラグメンテーションにも関わる支 配的な因子である.

負イオンモードは正イオンモードと比べると一般的とは 言いがたく敬遠されることが多いが，分析対象によっては 独特な構造情報を与える有用な分析モードになりうる。糖 鎖の場合は特にユニークな構造情報を与え, MSが苦手と する構造異性体解析を補完する意味でも有用な分析モード と言える。

\section{文献}

1) K. Mariño, J. Bones, J. J. Kattla, and P. M. Rudd, Nat. Chem. Biol., 6(10), 713 (2010).

2) A. Kameyama, N. Kikuchi, S. Nakaya, H. Ito, T. Sato, T. Shikanai, Y. Takahashi, K. Takahashi, and H. Narimatsu, Anal. Chem., 77(15), 4719 (2005).

3) A. Kameyama, S. Nakaya, H. Ito, N. Kikuchi, T. Angata, M. Nakamura, H. Ishida, and H. Narimatsu, J. Proteome Res., 5, 808 (2006).
4) D. J. Harvey, J. Am. Soc. Mass Spectrom., 16(5), 622 (2005).

5) D. J. Harvey, J. Am. Soc. Mass Spectrom., 16(5), 631 (2005).

6) D. J. Harvey, J. Am. Soc. Mass Spectrom., 16(5), 647 (2005).

7) D. J. Harvey, J. Jaeken, M. Butler, A. J. Armitage, P. M. Rudd, and R. A. Dwek, J. Mass Spectrom., 45(5), 528 (2010).

8) D. J. Harvey and P. M. Rudd, Int. J. Mass Spectrom., 305(2-3), 120 (2011).

9) D. J. Harvey, M. Edgeworth, B. a. Krishna, C. Bonomelli, S. a. Allman, M. Crispin, and J. H. Scrivens, Rapid Commun. Mass Spectrom., 28(18), 2008 (2014).

10) D. J. Harvey and J. L. Abrahams, Rapid Commun. Mass Spectrom., 30(5), 627 (2016).

11) M. Wuhrer, C. A. M. Koeleman, and A. M. Deelder, Anal Chem., 81(11), 4422 (2009).

12) B. Domon and C. E. Costello, Glycoconjugate J., 5(4), 397 (1988).

13) J. Amano, D. Sugahara, K. Osumi, and K. Tanaka, Glycobiology, 19(6), 592 (2009).

14) T. Nishikaze, S. Kawabata, and K. Tanaka, Anal. Chem., 86(11), 5360 (2014).

15) T. Nishikaze, K. Kaneshiro, S. Kawabata, and K. Tanaka, Anal. Chem., 84(21), 9453 (2012).

16) Y. Cai and R. B. Cole, Anal. Chem., 74(5), 985 (2002).

17) Y. Cai, Y. Jiang, and R. B. Cole, Anal. Chem., 75(7), 1638 (2003).

18) T. Yamagaki, H. Suzuki, and K. Tachibana, Anal. Chem., 77(6), 1701 (2005).

19) M. Rohmer, B. Meyer, M. Mank, B. Stahl, U. Bahr, and M. Karas, Anal. Chem., 82(9), 3719 (2010).

20) K. Kaneshiro, Y. Fukuyama, S. Iwamoto, S. Sekiya, and K. Tanaka, Anal. Chem., 83(10), 3663 (2011).

21) Y. Fukuyama, N. Funakoshi, K. Takeyama, Y. Hioki, T. Nishikaze, K. Kaneshiro, S. Kawabata, S. Iwamoto, and K. Tanaka, Anal. Chem., 86, 1937 (2014).

22) P. Domann, D. I. R. Spencer, and D. J. Harvey, Rapid Commun. Mass Spectrom., 26(4), 469 (2012)

23) T. Nishikaze, Y. Fukuyama, S. Kawabata, and K. Tanaka, Anal. Chem., 84(14), 6097 (2012).

24) K. Breuker, R. Knochenmuss, and R. Zenobi, J. Am. Soc. Mass Spectrom., 10, 1111 (1999).

25) S. Sekiya, K. Taniguchi, and K. Tanaka, Rapid Commun. Mass Spectrom., 26(6), 693 (2012).

26) T. Nishikaze, H. Tsumoto, S. Sekiya, S. Iwamoto, Y. Miura, and K. Tanaka, Anal. Chem., 89, 2353 (2017).

27) D. J. Harvey, C. A. Scarff, M. Crispin, C. N. Scanlan, C. Bonomelli, and J. H. Scrivens, J. Am. Soc. Mass Spectrom., 23(11), 1955 (2012).

28) W. Ni, J. Bones, and B. L. Karger, Anal. Chem., 85(6), 3127 (2013).

29) K. Breuker, R. Knochenmuss, and R. Zenobi, Int. J. Mass Spectrom., 184, 25 (1999). 